\title{
Population genetics of the common guillemot Uria aalge in the North Atlantic: geographic impact of oil spills
}

\author{
Lèa Riffaut ${ }^{1}$, Karen D. McCoy ${ }^{3}$, Claire Tirard ${ }^{2}$, Vicki L. Friesen ${ }^{4}$, Thierry Boulinier ${ }^{1,5, *}$ \\ ${ }^{1}$ Laboratoire d'Ecologie, CNRS UMR 7625 and ${ }^{2}$ Laboratoire de Parasitologie Evolutive, CNRS UMR 7103 , \\ Université Pierre et Marie Curie, 7 quai Saint Bernard, 75005 Paris, France \\ ${ }^{3}$ Génétique et Evolution des Maladies Infectieuses, CNRS-IRD UMR 2724, Institut de recherche pour le développement, \\ 911 Avenue Agropolis, BP 64501, 34394 Montpellier, France \\ ${ }^{4}$ Department of Biology, Queen's University, Kingston, Ontario K7L 3N6, Canada \\ ${ }^{5}$ Present address: Centre d'Ecologie Fonctionnelle et Evolutive, CNRS UMR 5175, 1919 Route de Mende, \\ 34293 Montpellier, France
}

\begin{abstract}
The population genetic structure of a species can be an important conservation tool informing us about the potential for genetic loss and the capacity for species recovery. Depending on the nature of population subdivision, it can also provide a means for assessing the source population of dead or injured individuals of unknown geographic origin. This type of information can be particularly useful in instances of large-scale environmental accidents, such as oil spills. Following the wreck of the 'Erika' oil tanker in the Bay of Biscay in December 1999, more than 80000 seabirds were washed ashore along the west coast of France. The most heavily affected species (80\% of all birds) was the common guillemot Uria aalge, a widespread long-lived colonial seabird. In an attempt to evaluate the 'true' geographic extent of this accident, we carried out population genetic analyses using 6 microsatellite markers on samples from 22 breeding colonies in the North Atlantic and on individuals collected after the oil spill. A pattern of isolation by distance was detected among common guillemot populations, but populations were only weakly structured, even at large spatial scales. The low level of genetic differentiation between colonies prevented clear assignments of oiled birds to their population of origin using only the genetic information. The weak genetic structure suggests that little genetic variability was lost during the oil spill and implies a high potential for population recovery via dispersal. However, current gene flow among extant colonies may overestimate the capacity of locally extinct colonies to recover due to the behavioural processes involved in recruitment. Clearly, the mortality of tens of thousands of high-latitude seabirds due to oil pollution warrants ongoing scientific scrutiny and conservation effort.
\end{abstract}

KEY WORDS: Assignment tests $\cdot$ Dispersal $\cdot$ Microsatellites $\cdot$ Marine pollution $\cdot$ Common guillemot Uria aalge $\cdot$ Colonial seabird

\section{INTRODUCTION}

Certain seabird species are particularly vulnerable to oil spills due to their ecology, behaviour and life-history traits (Piatt \& Lensink 1989, Piatt et al. 1990, Wiens et al. 1996, Begg et al. 1997, Irons et al. 2000, Peterson et al. 2003). The colonial breeding habits of most seabirds, with colonies varying in size from tens to hun- dreds of thousands of individuals, and their strong natal philopatry (tendency to return to breed where they were born) and breeding-site fidelity (Furness \& Monaghan 1987, Harris et al. 1996a,b) could make populations particularly sensitive to local extinctions or to losses of large numbers of individuals. In addition, due to the high annual survival rate of adults and low annual fecundity (several species lay only 1 egg per 
season), seabird populations can be highly sensitive to reductions in the survival of breeders (Wiens et al. 1984, Lebreton \& Clobert 1991). Moreover, changes in the condition of the local habitat can also lead foraging individuals to move elsewhere, thereby influencing habitat occupancy and use (Wiens 1996). Depending on the time of the year when an oil spill occurs, breeding colonies closest to the spill site are not necessarily the most heavily affected. Birds from numerous geographic locations often gather together at sea during winter, a time when inclement weather may increase the frequency of oil spills, illegal discharges and shipwrecks. Such migratory groups can be particularly vulnerable. The relative importance of these different effects is difficult to assess due to the large scales often involved and the logistical constraints in monitoring the fate of birds at sea. In this context, determining the origins of seabirds caught in an oil spill is critical for any attempt to assess its potential impact (Piatt \& Lensink 1989, Heubeck et al. 2003, Peterson et al. 2003), and population genetic approaches could provide valuable information.

Following the 'Erika' wreck in December 1999, more than 20000 tonnes of oil were released into the Bay of Biscay and spread along the west coast of France (Le Moigne \& Laubier 2004). This is an important wintering area for a large number of seabird species (Mead 1974, Brown 1985, Harris \& Swann 2002), and more than 80000 birds were found oiled along the French coast (Cadiou et al. 2004) Société pour l'Etude et la protection de la nature en Bretagne (Bretagne-Vivante -SEPNB) and Ligue pour la protection des oiseaux (LPO). Of these individuals, $80 \%$ were common guillemots, Uria aalge (Family Alcidae), of unknown origin.

To investigate the geographic origins of birds affected by the 'Erika' oil spill, several approaches could be used. The first is based on the biometrical features of recovered birds (Hope Jones 1996, Stratford \& Partridge 1996, Heubeck et al. 2003). For instance, the common guillemot is classified into 6 sub-species distributed along a north-south gradient in the North Atlantic. However, the actual description and distinctness of these sub-species is controversial (Bédard 1985, Brown 1985). Biometric methods are difficult to implement without a consensus on the morphological features to be used to characterize sub-species (Brown 1985). In addition, the spatial resolution of such a method can be imprecise (Cadiou et al. 2004). The second potential approach is based on ring recoveries (Baillie \& Mead 1982, Harris \& Swann 2002), which, while more reliable than biometry, also has some limitations. Typically, few oiled birds carry a ring, and as ringing has been intense in some areas but not in others, any inferences made from such techniques would likely be biased (Mead 1974, Harris \& Swann 2002, Cadiou et al. 2004). A third approach to determine the geo- graphical origin of affected individuals could be to use variation in the isotopic composition of sampled tissues, a method which reflects the natural variation of stable isotopes in the environment (Hobson 1999). Previous studies on seabirds have shown the potential of this technique to study migratory and wintering areas (Minami \& Ogi 1997, Cherel et al. 2000), but investigations in this field are currently limited by a relatively poor understanding of marine biogeographic isotopic regions and the identification of small-scale isotopic gradients in food webs (Hobson 1999, Forero \& Hobson 2003).

Here, we decided to use a fourth method that relies on highly polymorphic genetic markers to study the population structure of the common guillemot and to attempt to assign individuals to their population of origin. Assignment tests have been used to (1) identify individual dispersers (Paetkau et al. 1995, Rannala \& Mountain 1997), (2) estimate rates of dispersal between populations (Favre et al. 1997), (3) reconstruct genetic lineages (Nielsen et al. 1997), and (4) determine the origin of individuals for conservation or wildlife management (Edwards et al. 2001, Manel et al. 2002, Maudet et al. 2002, Scribner et al. 2003). The principle of these tests is to compare the multilocus genotype of an individual to genotypes found in different sampled populations. Each individual can then be assigned to the population where it has the strongest probability of belonging (Paetkau et al. 1995, Waser \& Strobeck 1998). The usefulness of this method depends on (1) the set of sampled populations and (2) the ability to characterize populations using the genotypes of individuals, which is higher if the populations are genetically structured (Cornuet et al. 1999). Studying population genetic structure can also provide information on natural levels of gene flow at different scales. This can be particularly useful for conservation as it gives us an idea of the risks of losing genetic variability and the capacity of local populations to recover via rescue effects and re-colonization following dramatic declines (Friesen 1997, Amos \& Balmford 2001, Hedrick 2001).

Predictions concerning the genetic structuring of seabird populations are conflicting. Until the last decade, population studies on intensively monitored sites have shown high philopatry and breeding-site fidelity in several widespread species, such as the common guillemot (Tuck 1961, Cramp 1985, Hudson 1985, Harris et al. 1996a), which could lead to population differentiation. However, it is now well known that young auks may settle and start breeding away from their natal colony (e.g. Harris \& Wanless 1991, Halley \& Harris 1993, Lyngs 1993, Harris et al. 1996a, Olsson et al. 1999, Harris \& Swann 2002). The effective dispersal of individuals between colonies could thus be strong enough to genetically homogenize populations. Weak 
population genetic differentiation has been reported for several seabird species (e.g. Atlantic puffin Fratercula arctica: Moen 1991; Brünnich's guillemot Uria lomvia: Birt-Friesen et al. 1992; common guillemot: Moum et al. 1991, Friesen et al. 1996b, Moum \& Arnason 2001; sooty tern Sterna fuscata: Avise et al. 2000; albatrosses, Thalassache spp.: Burg \& Croxall 2001, Adélie penguin Pygoscelis adelidae: Roeder et al. 2001; marbled murrelet Brachyramphus marmoratus: Congdon et al. 2000; northern fulmar Fulmarus glacialis: Burg et al. 2003; but see great frigatebird Fregata minor: Dearborn et al. 2003). Most of these studies have used markers that typically reflect the phylogeographic history of the species rather than provide information on current gene flow (e.g., mitochondrial DNA markers), and a call for the use of more polymorphic markers, such as microsatellites, has been made (Moum \& Arnason 2001). Microsatellites have become the marker of choice for many conservation studies because of their (1) expected neutrality, (2) abundance and broad distribution throughout the genome, and (3) relatively high polymorphism, even in bottlenecked populations and species with little polymorphism at other markers (e.g. Jarne \& Lagoda 1996, Parker et al. 1998, Gaggiotti et al. 1999, Sunnucks 2000).

The aim of this study was to use a population-genetics approach as a general tool to investigate the geographic impact of marine pollution on seabird species. In particular, we considered the 'Erika' oil spill, and the most heavily affected species, the common guillemot. We evaluated the genetic structure of common guillemot populations in the North Atlantic using neutral, hypervariable molecular markers (microsatellites) and samples from a large number of colonies. As previous molecular studies on this species used more historical markers (Moum et al. 1991, Friesen et al 1996b, Moum \& Arnasson 2001), this analysis provides new information on inter-colony gene flow of this abundant species in the North Atlantic. Using individuals sampled in different breeding colonies and ringed birds recovered following the oil spill, we then tested whether we could determine with certainty the geographical origin of oiled birds.

\section{MATERIALS AND METHODS}

The common guillemot. The common guillemot breeds in the Northern Hemisphere between $40^{\circ}$ and $70^{\circ}$. The North Atlantic breeding population is estimated at 3 million pairs, of which $85 \%$ are found along the eastern coast (Harris \& Wanless 2004). Northern colonies can be large (tens of thousands of breeding pairs), but colonies situated at the southern limit of the range, e.g., in France, Spain and Portugal, are typically small. Guillemots, like other auks, spend much time on the sea surface, making them particularly susceptible to oil pollution (Harris \&Wanless 2004). They are longlived birds, reaching sexual maturity at about 5 years of age (Harris et al. 2000). After overwintering at sea, they return in early spring to their breeding colony, typically on high, steep sea cliffs (Tuck 1961). They usually remain with the same mate between years and produce a maximum of 1 chick per year (Hudson 1985). Until recently, the individuals of this species were considered strongly philopatric and faithful to their breeding colony (Tuck 1961, Hudson 1985, Harris \& Wanless 1995, Harris et al. 1996a,b). Nevertheless, it is now well known that young guillemots visiting other colonies may settle and start breeding away from their natal colony (Halley \& Harris 1993, Lyngs 1993, Harris et al. 1996a).

Sampling and genotyping. A total of 678 common guillemot individuals were sampled from 22 colonies spread across the North Atlantic. Particular attention was given to the eastern North Atlantic (Britain and Ireland), the areas most likely to have been affected by the 'Erika' oil spill (Fig. 1, Table 1). As seabirds may form local kin groups within colonies (Friesen et al. 1996a), we attempted to sample in different areas within each colony. Samples from within each colony came from either breeding birds or chicks, to diminish the risks of sampling related or non-breeding individuals. In most colonies, blood samples were taken, although growing feathers and embryos were also used for DNA extractions (Table 1).

Following the oil spill, an effort was made to keep a representative sample of oiled birds. Among the large number of recovered guillemots, 1500 carcasses, gathered from several locations along the French coast, were frozen and used for DNA sampling. Samples of pectoral muscle from these individuals were collected and preserved in $95 \%$ ethanol. To evaluate the usefulness of the assignment method for determining the origins of these birds, we restricted our initial analysis to 48 ringed individuals for which the colony of origin was known (47 birds ringed in Britain, 1 in Germany).

DNA was extracted using a commercial kit (Perfect gDNA Blood Mini Isolation kit, Eppendorf). The same kit was used for solid tissue and feathers. All individuals were genotyped at 6 microsatellite loci. Three of these markers had been isolated previously for this species (Uaa5-8, Uaa23, Ibarguchi et al. 2000; HC6, GenBank accession number: AY359959). Three others were developed for related species (K32 from blacklegged kittiwake Rissa tridactyla, Tirard et al. 2002; Ulo22 and Ulo29 from Brünnich guillemot Uria lomvia, Ibarguchi et al. 2000). For 3 loci (Uaa5-8, Ulo22 and Uaa23), polymerase chain reactions (PCR) were carried out as outlined in McCoy \& Tirard (2000) using an 


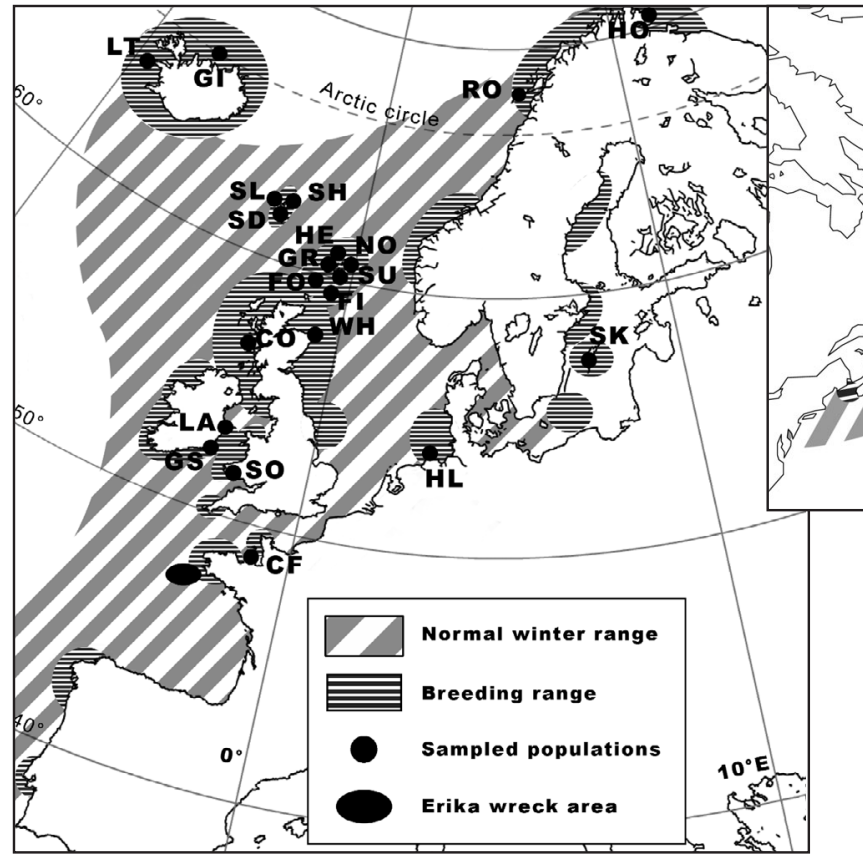

annealing temperature of $55^{\circ} \mathrm{C}$. PCR products were run on $6 \%$ polyacrylamide gels using size controls, and alleles were scored manually by 2 independent observers. The 3 other loci (Ulo29, Hc6, K32) were analysed using an automated sequencer (ABI Prism 310 Genetic Analyser, Applied Biosystems, PerkinElmer). For these markers, amplifications were performed in a $10 \mu$ l mixture containing approximately $50 \mathrm{ng}$ of genomic DNA, $75 \mu \mathrm{M}$ of each dNTP $(10 \mathrm{mM}$
Fig. 1. Uria aalge. Distribution of common guillemots in the North Atlantic (from Cramp 1985) and sampling locations (black circles). Population codes are indicated in Table 1

TrisHCl, $50 \mathrm{mM} \mathrm{KCl}$ and $1.5 \mathrm{mM} \mathrm{MgCl2}$ ), $0.4 \mu \mathrm{M}$ of each primer and $0.25 \mathrm{U}$ Taq DNA polymerase (Qiagen). Primers were labelled with fluorescent dyes. Amplifications were performed in a GeneAmp PCR System 9700 (Applied Biosystem) with initial denaturation of $12 \mathrm{~min}$ at $94^{\circ} \mathrm{C}, 30$ cycles of $15 \mathrm{~s}$ at $94^{\circ} \mathrm{C}, 15 \mathrm{~s}$ at $53^{\circ} \mathrm{C}$ and $30 \mathrm{~s}$ at $72^{\circ} \mathrm{C}$, and a final elongation step of $10 \mathrm{~min}$ at $72^{\circ} \mathrm{C}$. Alleles were scored via a labelled size standard (GENESCAN ROX 400HD) using the ABI

Table 1. Uria aalge. Origins and numbers of common guillemot samples

\begin{tabular}{|c|c|c|c|c|c|c|}
\hline Colony & Latitude & Longitude & Number & Sample type & Individuals & Origin \\
\hline Hornøya, Norway (HO) & $70^{\circ} 23^{\prime} \mathrm{N}$ & $31^{\circ} 09^{\prime} \mathrm{E}$ & 24 & Blood & Adults & T. Boulinier, K. McCoy \\
\hline Røst, Norway (RO) & $67^{\circ} 28^{\prime} \mathrm{N}$ & $11^{\circ} 59^{\prime} \mathrm{E}$ & 34 & Blood & Adults & T. Anker Nilsen \\
\hline Grimsey, Iceland (GI) & $66^{\circ} 33^{\prime} \mathrm{N}$ & $18^{\circ} 00^{\prime} \mathrm{W}$ & 28 & Blood & Adults & T. Boulinier, K. McCoy \\
\hline Latrabjarg, Iceland (LT) & $65^{\circ} 29^{\prime} \mathrm{N}$ & $24^{\circ} 28^{\prime} \mathrm{W}$ & 28 & Blood & Adults & T. Boulinier, K. McCoy \\
\hline Sandoy Liraberg, Faeroe isles (SL) & $61^{\circ} 54^{\prime} \mathrm{N}$ & $06^{\circ} 56^{\prime} \mathrm{W}$ & 15 & Embryos & Embryos & B. Olsen \\
\hline Sandoy Honin, Faeroe isles (SH) & $61^{\circ} 52^{\prime} \mathrm{N}$ & $06^{\circ} 55^{\prime} \mathrm{W}$ & 30 & Embryos & Embryos & B. Olsen \\
\hline Skuvoy Daer, Faeroe isles (SD) & $61^{\circ} 46^{\prime} \mathrm{N}$ & $06^{\circ} 49^{\prime} \mathrm{W}$ & 33 & Embryos & Embryos & B. Olsen \\
\hline Hermaness, Scotland (HE) & $60^{\circ} 50^{\prime} \mathrm{N}$ & $00^{\circ} 55^{\prime} \mathrm{W}$ & 30 & Blood & Adults & T. Boulinier, K. McCoy \\
\hline Grunay, Scotland (GR) & $60^{\circ} 39^{\prime} \mathrm{N}$ & $01^{\circ} 18^{\prime} \mathrm{W}$ & 30 & Blood & Adults & T. Boulinier, K. McCoy \\
\hline Noss, Scotland (NO) & $60^{\circ} 09^{\prime} \mathrm{N}$ & $01^{\circ} 01^{\prime} \mathrm{W}$ & 30 & Blood & Adults & T. Boulinier, K. McCoy \\
\hline Foula, Scotland (FO) & $60^{\circ} 08^{\prime} \mathrm{N}$ & $02^{\circ} 05^{\prime} \mathrm{W}$ & 33 & Blood & Adults & T. Boulinier, O. Duriez \\
\hline Sumburgh Head, Scotland (SU) & $59^{\circ} 51^{\prime} \mathrm{N}$ & $01^{\circ} 16^{\prime} \mathrm{W}$ & 31 & Blood & Adults & T. Boulinier, K. McCoy \\
\hline Fair Isle, Scotland (FI) & $59^{\circ} 32^{\prime} \mathrm{N}$ & $01^{\circ} 39^{\prime} \mathrm{W}$ & 26 & Blood & Adults & T. Boulinier, K. McCoy \\
\hline Whinnyfold, Scotland (WH) & $57^{\circ} 23^{\prime} \mathrm{N}$ & $01^{\circ} 51^{\prime} \mathrm{W}$ & 40 & Blood & Adults & T. Boulinier, K. McCoy \\
\hline Stora Karlso, Sweden (SK) & $57^{\circ} 17^{\prime} \mathrm{N}$ & $17^{\circ} 58^{\prime} \mathrm{E}$ & 30 & Feathers & Chicks & H. Osterblom \\
\hline Helgoland, Germany (HL) & $54^{\circ} 12^{\prime} \mathrm{N}$ & $07^{\circ} 53^{\prime} \mathrm{E}$ & 53 & Feathers & Chicks & O. Hueppop \\
\hline Colonsay, Scotland (CO) & $56^{\circ} 04^{\prime} \mathrm{N}$ & $06^{\circ} 13^{\prime} \mathrm{W}$ & 32 & Blood & Adults & T. Boulinier, K. McCoy \\
\hline Lambay, Ireland (LA) & $53^{\circ} 29^{\prime} \mathrm{N}$ & $06^{\circ} 01^{\prime} \mathrm{W}$ & 32 & Feathers & Chicks & O. J. Merne \\
\hline Great Saltee, Ireland (GS) & $52^{\circ} 07^{\prime} \mathrm{N}$ & $06^{\circ} 37^{\prime} \mathrm{W}$ & 32 & Feathers & Chicks & O. J. Merne \\
\hline Skromer, Wales (SO) & $51^{\circ} 45^{\prime} \mathrm{N}$ & $05^{\circ} 17^{\prime} \mathrm{W}$ & 30 & Blood & Adults & T. Birkhead \\
\hline Cap Fréhel, France (CF) & $48^{\circ} 25^{\prime} \mathrm{N}$ & $02^{\circ} 40^{\prime} \mathrm{W}$ & 22 & Blood & Chicks & T. Boulinier \\
\hline Witless Bay, Canada (WB) & $47^{\circ} 16^{\prime} \mathrm{N}$ & $52^{\circ} 48^{\prime} \mathrm{W}$ & 35 & Blood & Adults & V. Friesen \\
\hline
\end{tabular}


Prism GENESCAN analysis software (v 2.1). For the samples from the 2 Icelandic colonies, all loci were analysed using the automated sequencer with the above protocol.

Data analysis. Population genetic structure: Fisher's exact probability tests, employing a Markov chain, were performed to test for departure from HardyWeinberg expectations for each population and locus, and for tests of linkage disequilibrium across populations (GENEPOP v3.3, Raymond \& Rousset 1995). Significance levels were corrected for multiple tests (Rice 1989). Estimates of gene diversity (Nei 1987) and allelic richness in each population were computed using FSTAT (V2.9, Goudet 1995) and were compared among populations using a Kruskal-Wallis test (SAS Institute 1996). Population genetic structure was investigated using Wright's F-statistics (Weir \& Cockerham 1984). The significance of $F$-statistic estimates was tested using 5000 permutations based on resampling alleles or genotypes either among individuals or among populations (FSTAT v2.9, Goudet 1995). Confidence intervals were obtained by bootstrapping over loci (Goudet 1995). To examine gene flow in common guillemots at different spatial scales, we tested for isolation by distance using the correlation between genetic distance, measured as $F_{\text {st }} /\left(1-F_{\text {st }}\right)$, and geographic distance, measured as $\ln$ (distance), of population pairs (Rousset 1997). As common guillemots do not fly over land, geographic distances corresponded to the shortest distances by sea between 2 colonies $(\mathrm{km})$. Correlations were tested for significance using a Mantel permutation procedure (Mantel 1967) associated with Spearman rank correlation coefficients (GENEPOP v3.3, Raymond \& Rousset 1995).

Assignment tests: Assignment tests are only valid when populations are genetically structured (Cornuet et al. 1999, Manel et al. 2002, Maudet et al. 2002). To determine the reliability of the assignment tests for identifying the geographic origin of oiled birds, we first tested the method by attempting to assign the 678 individuals sampled in the 22 different colonies to their population of origin. As a second test, we used the same methods for assigning the 48 oiled ringed birds of known origin. We used the program GENECLASS (v4, Cornuet et al. 1999) which offers several methods for assigning individuals. We chose to use a likelihoodbased method based on a Bayesian approach derived from the assignment method of Rannala \& Mountain (1997) for computing the likelihood of a multilocus genotype occurring in a population. This method uses the allele frequencies of each population to compute the probability of occurrence of each multilocus genotype. We first used a direct assignment protocol to attribute each individual to the population to which its multilocus genotype had the highest probability of belonging. Then, to estimate the statistical certainty of each individual assignment, we used a simulation exclusion method to compute the probability of excluding each candidate population (using 10000 simulated individuals, significance threshold $=0.01$, Bayesian estimation of frequencies, and the 'Leave one out' procedure, which excludes the tested individual from its population when estimating allele frequencies). For each candidate population, this method compares the likelihood of occurrence of an individual's genotype to the distribution of genotypes generated by Monte Carlo simulations. If the likelihood of the genotype is outside the tail of the distribution (significance threshold), the population is excluded as the population of origin of the individual.

\section{RESULTS}

\section{Population genetic structure}

No linkage disequilibrium was observed between any of the 6 loci. After correction for multiple tests, only 3 populations - Foula, Helgoland and Witless Bay - were in Hardy-Weinberg disequilibrium (Table 2). For Foula and Helgoland, disequilibrium was caused

Table 2. Uria aalge. Estimates of genetic variability (mean \pm $\mathrm{SE}$ ) within common guillemot populations for 6 microsatellite loci. p-values refer to tests for deviations from HardyWeinberg equilibrium for each population. $\mathrm{n}$ refers to the number of individuals genotyped, $r$ to allelic richness, and $h$ to gene diversity. See Table 1 for colony abbreviations. Fis: Wright's inbreeding coefficient

\begin{tabular}{|lcccrc|}
\hline Colony & $\mathrm{n}$ & $r(\mathrm{SE})$ & $h(\mathrm{SE})$ & Fis & $\mathrm{p}$ \\
\hline $\mathrm{HO}$ & 21 & $5.48(1.05)$ & $0.68(0.07)$ & 0.108 & 0.030 \\
RO & 34 & $5.69(1.17)$ & $0.70(0.06)$ & 0.007 & 0.581 \\
GI & 28 & $5.18(0.91)$ & $0.68(0.06)$ & 0.065 & 0.036 \\
LT & 28 & $5.09(0.88)$ & $0.67(0.08)$ & 0.131 & 0.145 \\
SL & 15 & $5.05(1.09)$ & $0.67(0.07)$ & -0.051 & 0.052 \\
SH & 30 & $5.30(0.96)$ & $0.69(0.06)$ & 0.071 & 0.106 \\
SD & 33 & $5.09(1.04)$ & $0.64(0.08)$ & 0.000 & 0.941 \\
HE & 29 & $5.35(0.88)$ & $0.66(0.05)$ & 0.008 & 0.807 \\
GR & 28 & $5.32(0.96)$ & $0.67(0.06)$ & -0.034 & 0.161 \\
NO & 30 & $5.75(1.01)$ & $0.69(0.06)$ & 0.101 & 0.053 \\
FO & 31 & $5.52(0.98)$ & $0.70(0.05)$ & 0.009 & $<0.00001$ \\
SU & 31 & $5.26(0.91)$ & $0.68(0.04)$ & 0.053 & 0.560 \\
FI & 26 & $5.05(0.88)$ & $0.65(0.06)$ & 0.050 & 0.242 \\
WH & 40 & $5.54(1.09)$ & $0.69(0.05)$ & 0.018 & 0.700 \\
SK & 29 & $5.20(0.97)$ & $0.64(0.06)$ & 0.031 & 0.282 \\
HL & 49 & $5.55(0.92)$ & $0.68(0.05)$ & 0.107 & $<0.00001$ \\
CO & 32 & $4.90(0.87)$ & $0.66(0.06)$ & 0.006 & 0.286 \\
LA & 27 & $5.26(1.02)$ & $0.69(0.06)$ & 0.021 & 0.284 \\
GS & 32 & $5.58(1.01)$ & $0.71(0.05)$ & -0.016 & 0.894 \\
SO & 28 & $5.45(1.01)$ & $0.71(0.06)$ & 0.125 & 0.241 \\
CF & 22 & $5.65(0.84)$ & $0.70(0.05)$ & 0.048 & 0.558 \\
WB & 35 & $5.02(1.24)$ & $0.64(0.10)$ & 0.286 & 0.000 \\
\hline
\end{tabular}




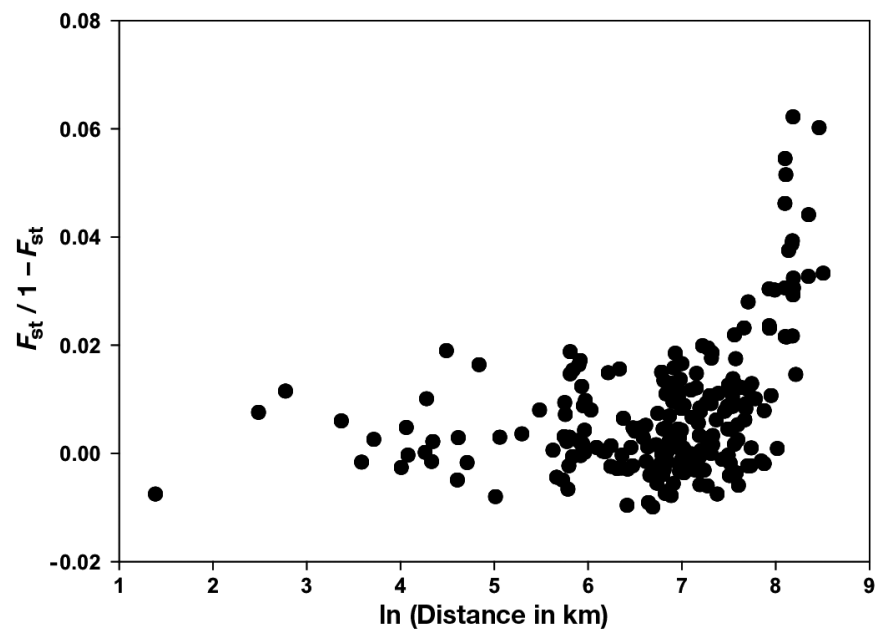

Fig. 2. Uria aalge. Pairwise genetic distance $\left(F_{\mathrm{st}} / 1-F_{\mathrm{st}}\right)$ vs. geographic distance (ln[distance] by sea) between populations of common guillemot

by a single locus in each population (K32 and Uaa23 respectively). For Witless Bay, however, 3 loci (K32, Ulo22 and Hc6) were in disequilibrium. The problem at the K32 locus, which also showed slight heterozygote deficits in other populations, is likely due to the presence of a null allele (Callen et al. 1993), as this marker was developed for another species. We show results that include K32, but all tests were also carried out without this locus, to verify that results were unaffected by it. DNA samples from Helgoland were difficult to amplify and the disequilibrium at the locus Uaa23 could be due to the difficulties in reading gels. Finally, because more than 1 locus was affected for Witless Bay, sub-structuring within this population (i.e. the Wahlund effect, Hartl \& Clark 1997) likely explains its deviation from Hardy-Weinberg equilibrium. Due to these 3 populations, alleles were not considered to be independent for testing the significance of population differentiation; permutation tests of $F_{\text {st }}$ used the genotype as the randomization unit instead of the allele (Goudet 1995).

Among populations, the average allelic richness varied from $4.90( \pm 0.87)$ to $5.75( \pm 1.01)$, and gene diversity ranged from $0.64( \pm 0.06)$ to $0.71( \pm 0.05)$ (Table 2$)$. However, neither parameter differed significantly among populations (Kruskall-Wallis tests; $\chi_{21}^{2}=1.86$, $p=1$ and $\chi_{21}^{2}=2.52, \mathrm{p}=1$ respectively). Overall population genetic differentiation was weak (average $F_{\text {st }}=0.005, \mathrm{p}=0.0014,95 \% \mathrm{CI}=0.004$ to 0.008 ). Results were similar when we excluded Witless Bay, the only population from the West Atlantic (average $F_{\text {st }}=0.004$, $\mathrm{p}=0.0036,95 \% \mathrm{CI}=0.002$ to 0.007 ). In pairwise exact tests for population differentiation, only 3 population pairs were significantly differentiated after correction for multiple tests: Witless Bay and Skuvoy, Witless Bay and Grunay, and Latrabjarg and Stora Karlso (see Table 3). For each of these 3 population pairs, differentiation was explained by a single locus.

Genetic and geographic distances were correlated (Fig. 2; $\mathrm{n}=231$, Spearman's $\mathrm{r}=0.39, \mathrm{p}<0.0001$ ). This relationship seems to show a threshold effect at distances greater than $3000 \mathrm{~km}$, distances that correspond to populations on either side of the North Atlantic. The same test performed without the most distant population (Witless Bay) resulted in a weaker, but still significant, correlation $(\mathrm{n}=210$, Spearman's $\mathrm{r}=0.19$, $\mathrm{p}=0.0051$ ). Thus, isolation by distance was principally explained by Witless Bay, the only population representing the western North Atlantic (Table 3).

\section{Assignment tests}

One of the assumptions of assignment tests is that there is Hardy-Weinberg equilibrium within the population (Cornuet et al. 1999). We therefore excluded the 3 populations for which this condition was not valid (Foula, Helgoland and Witless Bay) from this analysis. When we used the direct assignment method, only $6 \%$ of the 563 birds sampled from breeding colonies were correctly assigned to the population from which they were sampled (Fig. 3), i.e. only $6 \%$ of the individuals

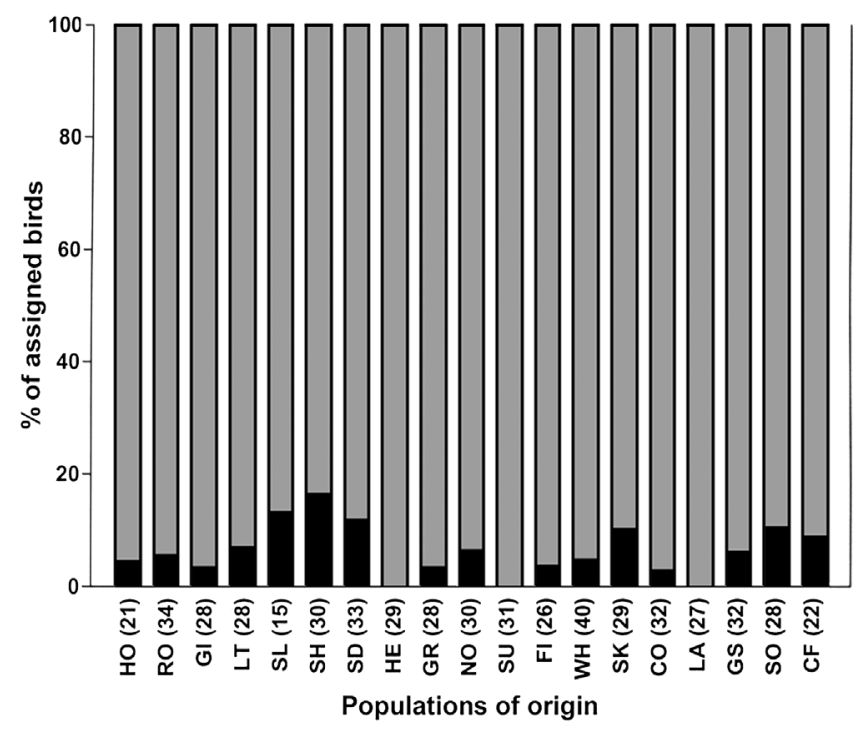

Fig. 3. Uria aalge. Direct assignments of the birds sampled from breeding colonies to populations. The black bars represent the percentage of individuals assigned to the population in which they were sampled, and the grey bars the percentage of birds assigned to another population. Note that we did not test samples from the populations which were in HardyWeinberg disequilibrium (Foula, Helgoland and Witless Bay). The numbers in brackets indicated the sample size of each population. See Table 1 for colony abbreviations 
were genetically closer to their population of origin than to any other sampled population. The results obtained using the exclusion simulation method were similar in that most birds could be assigned to several populations. Indeed, for over $70 \%$ of the 563 individuals sampled in the breeding colonies, none of the 19 populations were excluded as the possible source. The same general results were obtained for the 48 ringed birds. Overall, the weak level of genetic structure prevented reliable use of assignment tests.

\section{DISCUSSION}

Our study showed that common guillemot populations in the North Atlantic are only weakly differentiated at microsatellite loci. This is surprising when we consider that this species shows strong natal philopatry and breeding-site fidelity, and it exhibits recognized morphological polymorphisms at the population level: North Atlantic common guillemots have been classified into several sub-species based on plumage and morphometric differences among colonies (Bédard 1985, Brown 1985), and a north-south cline in the proportion of the bridled morph of individuals has been reported (Birkhead 1984).

Because the performance of assignment tests is strongly influenced by the level of population differentiation (Cornuet et al. 1999, Manel et al. 2002, Maudet et al. 2002), the weak differentiation in common guillemots means that we were not able to determine the origin of the oiled birds with much certainty. Indeed, only $6 \%$ of sampled individuals could be directly assigned to their colony of origin and for more than $70 \%$ of them, none of the 19 populations could be excluded as the colony of origin. Although our markers did not prove adequate for assigning individuals within the North Atlantic, this does not mean that a genetic approach may not be valid for other types of markers. Microsatellite markers are found within the nuclear genome and are considered to be neutral (i.e. unaffected by selection), making them ideal for examining population-level processes such as dispersal and changes in the effective number of breeders (see below). However, they may not reflect important adaptive variation, especially if there is mild gene flow or recent selection. A genetic marker that reflects adaptive differences could therefore prove useful for assigning individuals to their population or area of origin. Loci involved in the immune response (such as genes of the major histocompatibility complex, MHC) might be ideal markers, as these loci are highly variable and may be under strong selection given the frequency and intensity of parasitism in colonial seabirds and the potential for local adaptation (McCoy et al.

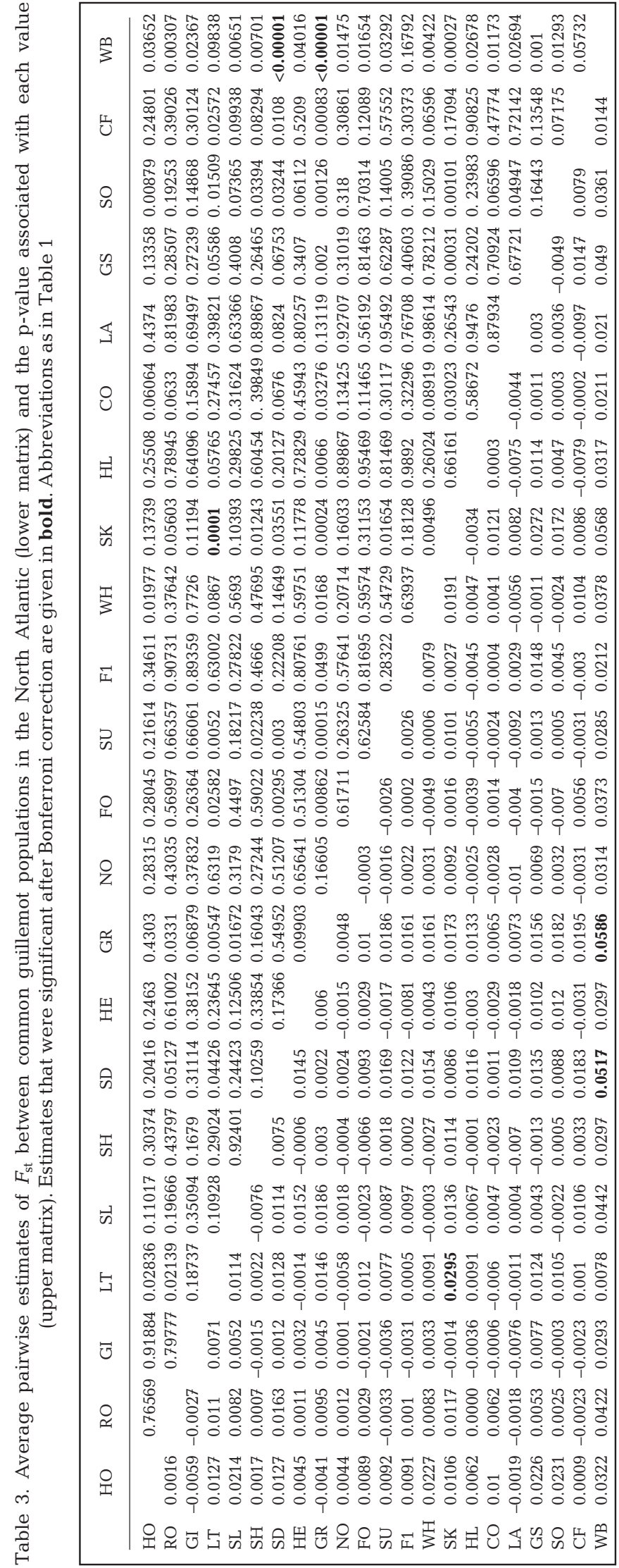


2003). Moreover, the results of biometry and ringrecovery analyses following the 'Erika' oil spill show that birds came from a wide area (Cadiou et al. 2004), and thus they stress the need to further explore reliable ways to identify the origin of oiled individuals.

This study provides important information about the genetic structure and functioning of common guillemot populations in the North Atlantic. Our results suggest that the populations of North-East Atlantic may be viewed as a single management unit (Friesen 1997, Hedrick 2001). The weak genetic differentiation at this spatial scale shows that from a genetic perspective the colonies constitute a single, large population, and the application of metapopulation theory to the population structure of common guillemots will undoubtedly be highly informative (Esler 2000). This idea of a single large population supports previous results obtained using mitochondrial markers (Moum et al. 1991, Friesen et al. 1996b, Moum \& Arnason 2001) and Friesen's (1997) hypothesis that the geographic scale of population genetic differentiation tends to be greater in species that undergo distant winter migrations or feed offshore compared to species that remain near the breeding colony or feed inshore. Overall, our results suggest that, despite the large number of guillemots killed in the 'Erika' oil spill, little genetic variation was lost and no genetically unique component of this species was harmed. This assumes, of course, that our markers are representative of the overall genetic characteristics of the populations; because our markers are neutral, there may be important selective variation that could not be assessed (see above).

The weak genetic structure of guillemot populations may be explained by several mutually-non-exclusive processes. First, the current populations could have been established from a single refugium after the last quaternary glaciation (Friesen et al. 1996b). Considering the mutation rate of microsatellites $\left(10^{-2}\right.$ to $10^{-5}$, that is, 1 mutation every 100 to 100000 replications generation $^{-1}$ for a given locus; Jarne \& Lagoda 1996), insufficient time may have elapsed since establishment of these populations to observe large genetic differences (Moum et al. 1991). Second, repeated bottlenecks followed by recolonization may contribute to the weak population-genetic structure of this species (Moum \& Arnason 2001). This hypothesis was proposed to explain the comparatively low mitochondrial variation for this species in addition to the weakly structured populations (Moum \& Arnason 2001). However, in the present study, we report levels of genetic diversity for microsatellite markers that are comparable or higher than those for other colonial seabird species (Burg 2000, Tirard et al. 2002, McCoy et al. in press). Finally, a lack of strong population structure can be the direct result of intercolony dispersal. Dispersal opposes the effect of genetic drift and tends to homogenize populations (Slatkin 1989). Intercolony dispersal has been assumed for some common guillemot populations in which colony size increased too quickly to be explained solely by the intrinsic growth rate (Tuck 1961, Nettleship \& Evans 1985, Lloyd et al. 1991). Resightings of ringed birds have also suggested that auks, including common guillemots, can disperse between breeding colonies at large spatial scales (Harris \& Wanless 1991, Halley \& Harris 1993, Lyngs 1993, Kampp \& Falk 1998, Harris \& Swann 2002). Immigrants could be attracted by high population densities that may indicate a strong survival rate, high reproductive success and better habitat quality (Nettleship \& Evans 1985, Lloyd et al. 1991). Although until the last decade it was assumed that common guillemots were highly philopatric (Tuck 1961, Cramp 1985, Hudson 1985), our results suggest that there may be enough large-scale gene flow to reduce genetic structure. This interpretation corroborates recent monitoring work on the dispersal abilities of this species (Halley \& Harris 1993, Lyngs 1993, Harris et al. 1996a, Harris \& Swann 2002). Nonetheless, our tests of isolation by distance were significant and thus suggest that dispersal may still be limited at larger spatial scales.

Information on the population functioning of the common guillemot can have important implications for conservation. In particular, relatively high intercolony dispersal would mean that populations may have a high capacity for recovery after local disasters. Population resilience may be a consequence of dispersal in combination with an increased number of first-time breeders due to the availability of vacant breeding sites (Cairns \& Elliot 1987, Croxall \& Rothery 1991, Wiens 1996). In many seabirds, pre-breeders prospect in their natal colonies, as well as in other colonies, before recruitment (Halley \& Harris 1993, Cadiou et al. 1994). Prospecting is now commonly viewed as a behavioural mechanism involved in habitat selection that allows an individual to assess environmental quality in different breeding areas using the presence and success of conspecifics (Boulinier et al. 1996, Danchin et al. 1998, Reed et al. 1999). For species in which individuals are attracted to conspecifics, local extinctions may occur when the size of local breeding groups decreases below a certain threshold (Allee effect). An important question is thus the time it takes for a species to re-colonize an area following local extinction. Depending on the colony of origin of the affected birds, and given the complex processes potentially involved in recolonization, the re-establishment of breeding numbers may be long, despite long-distance dispersal. 
Our results underline the need to combine information on the species distributions with a knowledge of the different process involved in the metapopulation dynamics of breeders in order to obtain a comprehensive assessment of the ecological impact of an oil spill on seabird populations. Investigations using model simulations under different scenarios should help to integrate the available information for seabirds sensitive to oil pollution. Such a study has, for instance, been performed to assess the potential impact of longline fisheries on wandering albatross Diomedea exulans populations (Inchausti \& Weimerskirch 2002). In the case of oil spills, which often occur when birds are away from the colonies, it is important to consider dispersal and the age structure of the population, along with the degree of subpopulation mixing that may vary with time of year. Such a modelling approach could allow one to use the available information to assess the consequences of a specific oil spill on different seabird populations, but also more generally to determine the scale and type of data needed to assess the potential impact on breeding populations.

The frequency of large oil spills has highlighted the fact that national authorities are often ill-prepared to manage such accidents (Camphuysen \& Heubeck 2001, Heubeck et al. 2003). Because spills can have major impacts on the marine environment, as well as on local economies and national politics, it is essential to reinforce preventative international conventions. From a conservation perspective, further work on methods to assess the geographic origins of oiled individuals and on predicting the population-level implications of spills is needed. Information on the population functioning of marine organisms, such as that revealed in the present study, should help us to move in this direction.

Acknowledgements. We are most grateful to T. A. Nilssen, V. Bakken, R. Barrett, T. Birkhead, B. Cadiou, O. Duriez, M. Frederiksen, B. Furness, J. Graves, P. Harvey, M. Heubeck, O. Hueppop, D. Jardine, O. Merne, S. Newton, B. Olsen, O. Olsson, H. Osterblom, A. Petersen, D. Shaw, S. Waugh and C. Wernham for helping with the collection of DNA samples of birds. We also thank Bretagne Vivante-SEPNB and LPO for allowing us to collect the tissue samples from oiled birds. E. Chapuis, H. Cabrera, M. Douadi, J. Gasparini, F. Helfelstein, A. Mordacque, T. Regembal, M. Fortin and M. Richard kindly helped at different stages of this work. Discussions with T. Tveraa and P. Fauchald were influential at early stages of the work. T. Burg, M. P. Harris and anonymous referees provided valuable comments on manuscript versions. We thank the various authorities that provided permits to collect samples. This project was financed by the French Ministry of Ecology (Programme 'Liteau-Erika') and benefited from support from the French Embassy of Canada (Fonds France-Canada pour la Recherche and Chateaubriand Post-doctoral award), the French Polar Institute (IPEV, Programme no. 333), the CNRS (France), NSERC, Canada and the Queen's University International Visitor Program (Canada).

\section{LITERATURE CITED}

Amos W, Balmford A (2001) When does conservation genetics matter? Heredity 87:257-265

Avise JC, Nelson WS, Bowen BW, Walker D (2000) Phylogeography of colonially nesting seabirds, with special reference to global matrilineal patterns in the sooty tern (Sterna fuscata). Mol Ecol 9:1783-1792

Baillie SR, Mead CJ (1982) The effect of severe oil pollution during the winter 1980-81 on British and Irish auks. Ring Migr 4:33-34

Bédard J (1985) Evolution and characteristics of the Atlantic Alcidae. In: Nettleship DN, Birkhead TR (eds) The Atlantic Alcidae. Academic Press, London, p 1-51

Begg GS, Reid JB, Tasker ML, Webb A (1997) Assessing the vulnerability of seabirds to oil pollution: sensitivity to spatial scale. Colon Waterbirds 20:339-352

Birkhead TR (1984) Distribution of the bridled form of the common guillemot Uria aalge in the North Atlantic. J Zool Lond 202:165-176

Birt-Friesen VL, Montevecchi WA, Gaston AJ, Davidson WS (1992) Genetic structure of thick-billed guillemot, Uria lomvia, populations examined using direct sequence analysis of amplified DNA. Evolution 46:267-272

Boulinier T, Danchin E, Monnat J-Y, Doutreland C, Cadiou B (1996) Timing of prospecting and the value of information in a colonial breeding bird. J Avian Biol 27:252-256

Brown RGB (1985) The Atlantic Alcidae at Sea. In: Nettleship DN, Birkhead TR (eds) The Atlantic Alcidae. Academic Press, London, p 384-426

Burg TM (2000) Genetic analyses of albatrosses: mating systems, population structure and taxonomy. PhD thesis, University of Cambridge, Cambridge

Burg TM, Croxall JP (2001) Global relationships amongst black-browed and grey-headed albatrosses: analysis of population structure using mitochondrial DNA and microsatellites. Mol Ecol 10:2647-2660

Burg TM, Lomax J, Almond R, Brooke M de L, Amos W (2003) Unravelling dispersal patterns in an expanding population of a highly mobile seabird, the northern fulmar (Fulmarus glacialis). Proc R Soc B 270:979-984

Cadiou B, Monnat JY, Danchin E (1994) Prospecting in the kittiwake, Rissa tridactyla: different behavioural patterns and the role of squatting in recruitment. Anim Behav 46: $847-856$

Cadiou B, Riffaut L, McCoy KD, Cabelguen J and 5 others (2004) Ecological impact of the 'Erika' oil spill: determination of the geographic origin of the affected common guillemots. Aquat Living Resour 17:369-377

Cairns DK, Elliot RD (1987) Oil spill impact assessment for seabirds: the role of refugia and growth centres. Biol Conserv 40:1-9

Callen DF, Thomson AD, Shen Y, Phillips HA, Richards RI, Mulley JC, Sutherland GR (1993) Incidence and origin of 'null' alleles in the $(\mathrm{AC})_{\mathrm{n}}$ microsatellite markers. Am J Hum Genet 52:922-927

Camphuysen CJ, Heubeck M (2001) Marine oil pollution and beached bird surveys: the development of a sensitive monitoring instrument. Environ Pollut 112:443-461

Cherel Y, Hobson KA, Weimerskirch H (2000) Using stableisotope analysis of feathers to distinguish moulting and breeding origins of seabirds. Oecologia 122:155-162

Congdon BC, Piatt JF, Martin K, Friesen VL (2000) Mechanism of population differentiation in marbled murrelets: historical versus contemporary processes. Evolution 54: 974-986

Cornuet JM, Piry S, Luikart G, Estoup A, Solignac M (1999) 
New methods employing multilocus genotypes to select or exclude populations as origins of individuals. Genetics 153:1989-2000

Cramp S (1985) Handbook of the birds of Europe, the Middle East and North America, vol 4. Oxford University Press, London

Croxall JP, Rothery P (1991) Population regulation of seabirds: implications of their demography for conservation. In: Perrins CM, Lebreton JD, Hirons GJM (eds) Bird population studies. Oxford University Press, London, p 272-296

Danchin E, Boulinier T, Massot M (1998) Conspecific reproductive success and breeding habitat selection: implication for the study of coloniality. Ecology 79:2415-2428

Dearborn DC, Anders AD, Schreiber EA, Adams MM, Mueller UG (2003) Inter-island movements and population differentiation in a pelagic seabird. Mol Ecol 12:2835-2843

Edwards SV, Silva MC, Burg T, Friesen VL, Warheit KI (2001) Molecular genetic markers in the analysis of seabird bycatch populations. In: Melvin E, Parrish J (eds) Seabird bycatch: trends, roadblocks and solutions. University of Alaska Sea Grant, Fairbanks, AK, p 115-140

Esler D (2000) Applying metapopulation theory to conservation of migratory birds. Conserv Biol 14:366-372

Favre L, Balloux F, Goudet J, Perrin N (1997) Female-biased dispersal in the monogamous mammal, Crocidura russula: evidence from field data and microsatellite patterns. Proc R Soc B 264:127-132

Forero MG, Hobson KA (2003) Using stable isotopes of nitrogen and carbon to study seabird ecology: applications in the Mediterranean seabird community. Sci Mar 67: S23-S32

Friesen VL (1997) Population genetics and the spatial scale of conservation of colonial waterbirds. Colon Waterbirds 20: 353-368

Friesen VL, Montevecchi WA, Gaston AJ, Barrett RT, Davidson WS (1996a) Molecular evidence for kin groups in the absence of large-scale genetic differentiation in a migratory bird. Evolution 50:924-930

Friesen VL, Montevecchi WA, Baker AJ, Barrett RT, Davidson WS (1996b) Population differentiation and evolution in the common guillemot Uria aalge. Mol Ecol 5:793-805

Furness RW, Monaghan P (1987) Seabird ecology. Blackie, Glasgow

Gaggiotti OE, Lange O, Rassmann K, Gliddons C (1999) A comparison of two indirect methods for estimating average levels of gene flow using microsatellite data. Mol Ecol 8:1513-1520

Goudet J (1995) FSTAT (vers.1.2): a computer program to calculate F-statistics. J Hered 86:485-486

Halley DJ, Harris MP (1993) Intercolony movement and behaviour of immature guillemots Uria aalge. Ibis 135: 264-270

Harris MP, Swann B (2002) Common guillemot. In: Wernham CV, Toms MP, Marchant JH, Clark JA, Siriwardena GM, Baillie SR (eds) The migration atlas: movements of birds of Britain and Ireland. T \& AD Poyser, London, p 397-400

Harris MP, Wanless S (1991) Population studies and conservation of puffins Fratercula artica. In: Perrins CM, Lebreton JD, Hirons GJM (eds) Bird population studies: their relevance to conservation and management. Oxford University Press, London, p 230-248

Harris MP, Wanless S (1995) Survival and non-breeding of adult common guillemots Uria aalge. Ibis 137:192-197

Harris MP, Wanless S (2004) Common guillemot Uria aalge. In: Mitchell PI, Newton SF, Ratcliffe N, Dunn TE (eds) Seabird populations of Britain and Ireland. T \& AD Poyser,
London, p 350-363

Harris MP, Halley DJ, Wanless S (1996a) Philopatry in the common guillemot Uria aalge. Bird Study 43:134-137

Harris MP, Wanless S, Barton TR (1996b) Site use and fidelity in the common guillemot Uria aalge. Ibis 138:399-404

Harris MP, Wanless S, Rothery P, Swann RL, Jardine DJ (2000) Survival of adult common guillemots Uria aalge at three Scottish colonies. Bird Study 47:1-7

Hartl DL, Clark AG (1997) Principles of population genetics, 3rd edn. Sinauer, Sunderland, MA

Hedrick PW (2001) Conservation genetics: where are we now? Trends Ecol Evol 16:629-636

Heubeck M, Camphuysen KCJ, Bao R, Humple D, Sandoval Rey A, Cadiou B, Brager S, Thomas T (2003) Assessing the impact of major oil spills on seabird populations. Mar Pollut Bull 46:900-902

Hobson KA (1999) Tracking origins and migration of wildlife using stable isotopes: a review. Oecologia 120:314-326

Hope Jones P (1996) The European cline in wing-length of guillemots Uria aalge. Seabird 11:19-21

Hudson PJ (1985) Population parameters for the Atlantic Alcidae. In: Nettleship DN, Birkhead TR (eds) The Atlantic Alcidae. Academic Press, London, p 233-261

Ibarguchi G, Birt TP, Warheit KI, Boag PT, Friesen VL (2000) Microsatellite loci from common and thick-billed guillemots, Uria aalge and U. lomvia. Mol Ecol 9:638-639

Inchausti P, Weimerskirch H (2002) Dispersal and metapopulation dynamics of an oceanic seabird, the wandering albatross, and its consequences for its response to longline fisheries. J Anim Ecol 71:765-770

Irons DB, Kendall SJ, Erickson WP, McDonald LL, Lance BK (2000) Nine years after the Exxon Valdez oil spill: effects on marine bird populations in Prince William Sound, Alaska. Condor 102:723-737

Jarne P, Lagoda PJL (1996) Microsatellites, from molecules to populations and back. Trends Ecol Evol 11:424-429

Kampp K, Falk K (1998) A long distance colony shift by a thick-billed murre. Colon Waterbirds 21:91-93

Lebreton JD, Clobert J (1991) Bird population dynamics, management and conservation: the role of mathematical modelling. In: Perrins CM, Lebreton JD, Hirons GJM (eds) Bird population studies: their relevance to conservation and management. Oxford University Press, London, p 105-125

Le Moigne M, Laubier L (2004) The Erika oil spill: environmental contamination and effects in the Bay of Biscay. Aquat Living Resour 17:235-236

Lloyd C, Tasker ML, Partridge K (1991) The status of seabirds in Britain and Ireland. T \& AD Poyser, London

Lyngs P (1993) Colony interchange in Baltic guillemots Uria aalge. Dan Ornitol Foren Tidsskr 87:247-250

Manel S, Berthier P, Luikart G (2002) Detecting wildlife poaching: identifying the origin of individuals with Bayesian assignment tests and multilocus genotypes. Conserv Biol 16:650-659

Mantel N (1967) The detection of disease clustering and a generalized regression approach. Cancer Res 27:209-220

Maudet C, Miller C, Bassano B, Breitenmoser-Würsten C, Gauthier D, Obexer-Ruff G, Michallet J, Taberlet P, Luikart G (2002) Microsatellite DNA and recent statistical methods in wildlife conservation management: applications in alpine ibex, Capra ibex (ibex). Mol Ecol 11:421-436

McCoy KD, Tirard C (2000) Isolation and characterization of microsatellites in the seabird ectoparasite Ixodes uriae. Mol Ecol 9:2213-2214

McCoy KD, Boulinier T, Tirard C, Michalakis Y (2003) Hostdependent genetic structure of parasite populations: dif- 
ferential dispersal of seabird tick host races. Evolution 57 : $288-296$

McCoy KD, Boulinier T, Tirard C (in press) Comparative hostparasite population structures: disentangling, prospecting and dispersal in the Black-legged Kittiwake Rissa tridactyla. Mol Ecol

Mead CJ (1974) The results of ringing auks in Britain and Ireland. Bird Study 21:45-86

Minami H, Ogi H (1997) Determination of migratory dynamics of the sooty shearwater in the Pacific using stable carbon and nitrogen isotopes analysis. Mar Ecol Prog Ser 158: 249-256

Moen SM (1991) Morphologic and genetic variation among breeding colonies of the Atlantic puffin (Fratercula arctica). Auk 108:755-763

Moum T, Arnason E (2001) Genetic diversity and population history of two related seabird species based on mitochondrial DNA control region sequences. Mol Ecol 10: 2463-2478

Moum T, Erikstad KE, Bjorkild E (1991) Restriction fragment analysis of mitochondrial DNA in common guillemots, Uria aalge, from four Norwegian seabird colonies. Can J Zool 69:1577-1584

Nei M (1987) Molecular evolutionary genetics. Columbia University Press, New York

Nettleship DN, Evans PGH (1985) Distribution and status of the Atlantic Alcidae. In: Nettleship DN, Birkhead TR (eds) The Atlantic Alcidae. Academic Press, London, p 82-102

Nielsen EE, Hansen MN, Loeschcke V (1997) Analysis of microsatellite DNA from old scale samples of Atlantic salmon Salmo salar: a comparison of genetic composition over 60 years. Mol Ecol 6:487-492

Olsson O, Fransson T, Larsso K (1999) Post fledging migration of common murres Uria aalge in the Baltic Sea: management implications. Ecography 22:233-239

Paetkau D, Calvert W, Striling I, Strobeck C (1995) Microsatellite analysis of population structure in Canadian polar bears. Mol Ecol 4:347-354

Parker PG, Snow AA, Schug MD, Booton GC, Fuerst PA (1998) What molecules can tell us about populations: choosing and using a molecular marker. Ecology 79:361-382

Peterson CH, Rice SD, Short JW, Esler D, Bodkin JL, Ballachey BE, Irons DB (2003) Long-term ecosystem response to the Exxon Valdez oil spill. Science 302:2082-2086

Piatt JF, Lensink CJ (1989) Exxon Valdez bird toll. Nature 342:865-866

Piatt JF, Lensink CJ, Butler W, Kendziorek M, Nysewander R (1990) Immediate impact of the Exxon Valdez oil spill on marine birds. Auk 107:387-397

Editorial responsibility: Otto Kinne (Editor-in-Chief), Oldendorf/Luhe, Germany
Rannala B, Mountain JL (1997) Detecting immigration by using multilocus genotypes. Proc Natl Acad Sci USA 94: 9197-9201

Raymond M, Rousset F (1995) GENEPOP (vers. 1.2): population genetic software for exact tests and ecumenicism. J Hered 86:248-249

Reed JM, Boulinier T, Danchin E, Oring LW (1999) Informed dispersal: prospecting by birds for breeding sites. Curr Ornithol 15:189-259

Rice WR (1989) Analysing tables of statistical tests. Evolution 43:223-225

Roeder AD, Marshall RK, Mitchelson AJ, Visagathilagar T, Ritchie PA and 7 others (2001) Gene flow on the ice: genetic differentiation among Adelie penguin colonies around Antarctica. Mol Ecol 10:1645-1656

Rousset F (1997) Genetic differentiation and gene flow from F-statistics under isolation by distance. Genetics 145: $1219-1228$

SAS Institute (1996). SAS user's manual. SAS Institute, Cary, $\mathrm{NC}$

Scribner KT, Warrillow JA, Leafloor JO, Prince HH, Inman RL, Luukkonen DR, Flegel CS (2003) Genetic methods for determining racial composition of Canada goose harvest. J Wildl Manag 67:122-135

Slatkin M (1989) Detecting small amounts of gene flow from phylogenies of alleles. Genetics 121:609-612

Stratford JM, Partridge KE (1996) An analysis of biometrics of oil contaminated common guillemots Uria aalge in SouthWest Britain 1980-1994. Seabird 18:38-43

Sunnucks P (2000) Efficient genetic markers for population biology. Trends Ecol Evol 15:199-203

Tirard C, Helfenstein F, Danchin E (2002) Polymorphic microsatellites in the black-legged kittiwake, Rissa tridactyla. Mol Ecol Notes 2:431-433

Tuck LM (1961) The Murres. Canadian Wildlife Service Monograph Ser. No. 1, Ottawa

Waser PM, Strobeck C (1998) Genetic signatures of interpopulation dispersal. Trends Ecol Evol 13:43-44

Weir BS, Cockerham CC (1984) Estimating F-statistics for the analysis of population structure. Evolution 38:1358-1370

Wiens JA (1996) Oil, seabirds and science. BioScience 46 587-597

Wiens JA, Ford RG, Heinemann D (1984) Information needs and priorities for assessing the sensitivity of marine birds to oil spill. Biol Conserv 28:21-49

Wiens JA, Crist TO, Day RH, Murphy SM, Hayward GD (1996) Effects of the Exxon Valdez oil spill on marine bird communities in Prince William Sound, Alaska. Ecol Appl $6: 828-841$

Submitted: September 2, 2004; Accepted: November 23, 2004 Proofs received from author(s): April 12, 2005 